\title{
Common risk factors of Lung cancer, an observational study in a National Institute, Dhaka
}

\author{
Bodiuzzaman $\mathrm{MM}^{1}$, Hussain $\mathrm{MZ}^{2}$, Morshed $\mathrm{SMM}^{3}$, Islam $\mathrm{MR}^{4}$, Akhtaruzzaman $\mathrm{M}^{5}$ \\ Asaduzzaman $\mathrm{M}^{6}$, Khatun $\mathrm{N}^{7}$, Akhter $\mathrm{PS}^{8}$
}

\begin{abstract}
Lung cancer is the most prevalent malignant neoplasm in most of the countries, and is leading cause of mortality worldwide. Till date tobacco consumption is the main etiological factor in lung carcinogenesis. Other factors such as genetic susceptibility, poor diet, occupational exposures and air pollution may act independently. Treatment of lung cancer is time consuming, costly and need special care during its management. Post treatment complications also more and sometimes it is more serious and becomes life threatening to the patients. The study was done to find out the most common risk factors of lung cancer, for this we can take necessary preventive measure from those risk factors to prevent health burden and mortality from lung cancer.This observational study was done in the department of Medical Oncology, National Institute of Cancer Research and Hospital (NICRH), Mohakhali, Dhaka, from January 2012 to May 2012. One hundred and six (106) patients, aged over 30 years, included all sexes, were diagnosed as a lung cancer by histopathology and came for chemotherapy, were selected randomly in this study after informed written consent. In this study we found males are predominantly affected (92.45\%) by lung cancer and common age groups affected are between 51-60 years (39.62\%). Among the occupation farmers are more affected $(77.35 \%)$ and most of them were active smokers $(64.15 \%)$. In our study we found that right side of lung is more affected (58.49\%) than left side and adenocarcinoma was predominant (35.84\%). Control of tobacco smoking is the most important preventive measure. This study may help us to identify the etiological aspect and future preventive efforts and research be needed to focus on tobacco smoking and non-cigarette tobacco smoking products, as well as better understanding of risk factors underlying lung carcinogenesis in never-smokers.
\end{abstract}

CBMJ 2019 January: vol. 08 no. 01 P: 23-29

Key words: Lung cancer, Risk factors, Smoking

\section{Introduction}

Lung cancer is the most frequent malignant neoplasm among men in most countries and the main cause of cancer death in both sexes. Despite the success in delineation of tobacco smoking as the major risk factor for lung cancer, this highly preventable disease remains among the most common and most lethal cancers globally. 1.38 million Deaths (18.2\% of the total) by 2008 in the world (Ferlay et al., 2010) ${ }^{1}$ and almost half $(49.9 \%)$ of the lung cancer cases occur in the developing countries (Siegel et al., 2013). ${ }^{2}$ Accounting for an estimated $27 \%$ of total cancer deaths in the USA in 2015 and $20 \%$ in the European Union (EU) in $2016 .^{3}$

According to GLOBOCAN (Global Cancer Observatory), in 2012 lung cancer accounted for an estimated 1242000 new
1. Dr. M. M. Bodiuzzaman; Assistant Professor (Medicine); Faridpur Medical College.

2. Dr. Muhammad Zubaer Hussain; Assistant Professor (Medicine); Sher E Bangla Medical College, Barishal.

3. Dr. S. M. Munawar Morshed; Assistant Professor (Radiotherapy), Faridpur Medical College.

4. Dr. Md. Rafiqul Islam; Assistant Professor (Medical Oncology) NICRH; Mohakhali, Dhaka.

5. Dr. Md Akhtaruzzaman; Registrar (Medical Oncology) NICRH; Mohakhali, Dhaka.

6. Dr. Md Asaduzzaman; Assistant Registrar (Medical Oncology) NICRH; Mohakhali, Dhaka.

7. Dr. Nazrina Khatun; Associate Professor (Medical Oncology) NICRH; Mohakhali, Dhaka.

8. Dr. Parveen Sahida Akhter; Professor \& Head (Medical Oncology), NICRH; Mohakhali, Dhaka.

Address of correspondence:

Email: drbodiuzzaman72@gmail.com Mobile: 01763-771144 
cases among men, which is $17 \%$ of all cancers excluding non-melanoma skin cancer, and 583000 (9\%) of new cancer cases among women. Approximately $58 \%$ of all cases occur in middle- and lowincome countries. ${ }^{4}$ Lung cancer also accounts for $19 \%$ of all cancer deaths. ${ }^{5}$ Among both women and men, the incidence of lung cancer is low in people aged $<40$ years and increases up to age 60 years and above.

Tobacco smoking is the major cause of all major histological types of lung cancer. Approximately 20 potential carcinogens of $\sim 3,500$ chemicals have been detected in a burning cigarette. The most established are the polycyclic aromatic hydrocarbons $(\mathrm{PAH})$ like benzo(a) pyrenes, and the tobacco-specific N-nitrosamine 4(methylnitrosamino)-1-(3-pyridyl)-1-

butanone (NNK), while others include Aszarenes, Dibenz $(\mathrm{a}, \mathrm{h})$ acridine, inorganic compounds like cadmium, chromium, nickel, arsenic, radioactive polonium (Po210) and organic compounds like butadiene. ${ }^{6}$ Nitrates in the tobacco are reduced to $\mathrm{NH}_{2}^{-}$and $\mathrm{NH} 3$ while smoking. Air-cured tobacco contains higher concentrations of aromatic amines as compared to flue-cured tobaccos (e.g. the urinary bladder carcinogens $\beta 2$ naphthylamine and 4-aminobiphenyl). ${ }^{7}$ Cigarette smoke contains high levels of acrolein, which is toxic to the ciliated lining of the lungs, and other agents such as nitrogen oxides, acetaldehyde, phenols, and formaldehyde, which may contribute indirectly to pulmonary carcinogenicity in animals and humans. Cigarette smoke also contains free radicals (FR) (e.g. hydrogen peroxide $\left[\mathrm{H}_{2} \mathrm{O}_{2}\right]$, hydroxyl ion $\left[\mathrm{OH}^{-}\right]$, sulfoxide anion) which induce oxidative damage in animal models as well as humans, while catechol and hydroquinone play their roles in single strand DNA breaks caused by the release of $\mathrm{FR}^{8}$

There is evidence from case-control studies that a diet rich in vegetables and fruits, especially cruciferous vegetables, may exert some protective effect against lung cancer. ${ }^{9,10}$ Here is evidence from observational studies that low levels of vitamin $D$ are associated with lung cancer risk $^{11}$ however, results of randomized trials do not provide supportive evidence.

Coffee drinking has been associated with lung cancer as coffee drinkers were more likely to be smokers than non-coffee drinkers. $^{12}$ Also, no evidence of an increased risk has been reported in studies of never-smokers. ${ }^{10}$ There is some evidence of a chemo preventive effect of tea, notably green tea, in smokers. ${ }^{13}$ However, the overall evidence is not consistent.

Patients with chronic obstructive pulmonary disease are at increased risk for lung cancer, and a number of studies have suggested that this is independent of smoking. ${ }^{14-16}$ Patients with pulmonary tuberculosis have been found to be at increased risk of lung cancer. ${ }^{17}$

Exposure to ionizing radiation increases the risk of lung cancer. ${ }^{18}$ This increased risk has been reported in atomic bomb survivors, as well as patients treated with radiotherapy (RR 1.5-2 for cumulative exposure in excess of $100 \mathrm{cGy}{ }^{19}$

Occupational exposures play a significant role in lung cancer aetiology, and the risk of lung cancer is increased among workers employed in a number of industries and occupations. ${ }^{20}$ Two studies have reported an estimate of the proportion of lung cancer cases attributable to occupational agents in the UK to be $14.5 \%$ overall $^{21}$ and $12.5 \%$ in men in France. ${ }^{22}$ The most important occupational lung carcinogens are reported to be asbestos, silica, radon, heavy metals and polycyclic aromatic hydrocarbons.

\section{Material and Methods}

This retrospective observational study was done in the department of Medical Oncology, National Institute of Cancer Research and Hospital (NICRH), Mohakhali, Dhaka, from January 2012 to May 2012. One hundred and six (106) patients, aged over 30 years were diagnosed as lung cancer by histopathology and came for chemotherapy, were selected randomly. Informed written consent was taken during 
data collection in a questioner form. Patients were included in this study, who gave voluntary consent, clear history regarding risk factors and whose histopathological reports support confirm diagnosis. Patients were excluded from this study those didn't give voluntary consent, clear history about risk factors and whose histopathological reports were not adequate. A proforma was designed to collect information regarding various parameters like age, sex, occupation, risk factors, diagnostic tools, site of cancer and histopathological types. All relevant data were collected, edited, organized into tables and analyzed by SPSS computerized program.

\section{Results}

Age and sex distribution:

\begin{tabular}{|l|c|}
\hline Age (in years) & No. of patients(\%) \\
\hline$<40$ & $04(3.77)$ \\
\hline $40-50$ & $24(22.64)$ \\
\hline $51-60$ & $42(39.62)$ \\
\hline $61-70$ & $30(28.30)$ \\
\hline $70-80$ & $06(5.66)$ \\
\hline Sex & \\
\hline Male & $98(92.45)$ \\
\hline Female & $08(7.54)$ \\
\hline
\end{tabular}

Table I: Age and sex distribution

Table I shows, among the patients diagnosed as lung cancer age ranges from 35 - 80 years with median age 55 years. Age less than 40 years were 04 (3.7\%), 40-50 years 24 (22.64\%), 51-60 years 42 (39.62\%), $61-70$ years 30 (28.3\%) and $70-80$ years $06(5.6 \%)$.

Regarding gender distribution male 98(92.45\%) and female 08(7.54\%).

\section{Occupation profile:}

\begin{tabular}{|l|c|}
\hline Occupation & No. of patients(\%) \\
\hline Farmer & $82(77.35)$ \\
\hline Businessman & $11(10.37)$ \\
\hline Official worker & $09(8.49)$ \\
\hline Housewife & $04(3.77)$ \\
\hline
\end{tabular}

Table II: Occupation chart

Table II shows, Farmer 82(77.35\%), Businessman 11(10.37\%), Official worker 09(8.49\%) and Housewife 04(3.77\%).
Risk factors:

\begin{tabular}{|l|c|}
\hline Risk factors & No. of patients(\%) \\
\hline Active smoker & $68(64.15)$ \\
\hline Ex-smoker & $20(18.86)$ \\
\hline Nonsmoker( $\mathrm{n}=18)$ 16.98\% & \\
\hline No cause found & $07(6.60)$ \\
\hline Use of biofuel & $05(4.71)$ \\
\hline COPD & $04(3.77)$ \\
\hline Evidence of arsenicosis & $02(1.88)$ \\
\hline Pack year(among smokers) & \\
\hline$>40$ & $58(54.71)$ \\
\hline $30-40$ & $19(17.92)$ \\
\hline$<30$ & $11(10.37)$ \\
\hline
\end{tabular}

Table III: Distribution of risk factors

Table III shows active smoker 68 (64.15\%), ex-smoker 20 (18.86\%), nonsmoker $18(16.98 \%)$ and among this no cause was found in $07(6.60 \%)$ patients. Among smokers most of the patients smokes $>40$ pack year $(54.71 \%)$

\section{Site and types of lung cancer:}

\begin{tabular}{|c|c|}
\hline Site of lung involvement & No. of patients (\%) \\
\hline Right lung & $62(58.49)$ \\
\hline Left lung & $44(41.50)$ \\
\hline \multicolumn{2}{|l|}{ Histopathological types } \\
\hline Small cell lung cancer (SCLC) & $22(20.25)$ \\
\hline Non-small cell lung cancer (NSCLC) & $84(79.25)$ \\
\hline Adenocarcinoma & $38(35.84)$ \\
\hline Squamous cell carcinoma & $18(16.98)$ \\
\hline Large cell carcinoma & $15(14.15)$ \\
\hline Anaplastic carcinoma & $09(8.50)$ \\
\hline Others & $04(3.77)$ \\
\hline
\end{tabular}

Table IV: Site and major histo-pathological type

Table IV shows Right sided lung cancer was $62(58.49 \%)$, and left sided 44(41.50\%). Among the histo-pathological types of lung cancer, Small cell lung cancer $22(20.25 \%)$ and non-small cell lung cancer $84 \quad$ (79.24\%). Adenocarcinoma 38 (35.84\%), Squamous cell carcinoma 18 (16.98\%), Large cell carcinoma $15(14.15 \%)$, Anaplastic cell carcinoma $09(8.50 \%)$ and others 04 $(3.77 \%)$. 


\section{Discussion:}

Lung cancer mainly occurs in older person and most people diagnosed with lung cancer are 65 years and above, very small number of people is younger than 45 years. But in our study we found lung cancer more in under age of 60 years. This may be due to we have no actual birth registration at the time of birth so the patients have no idea about their actual age. Most of them hide their age to doctors. They start smoking at early age and smoke more than usual. They use cigarette without filter. Genetic factors also may be the cause of early lung cancer and patient with genetic susceptibility who smoke increase the risk of lung cancer. But in western countries they are well educated and have birth registration at the time of birth and their life expectancy is more than our country.

In this study male affected predominantly ( $92.45 \%$ male compared to $7.54 \%$ female) because male consume more cigarette than female. Due to religious background of our country, most of Muslim women avoid smoking. Males start smoking in early part of their life and consume more than female. Male persons are also exposed to outside dusts and other biohazards than to female. But in western country this figure is different because they smoke more cigarette than our female population. In western countries the incidence of lung cancer is also higher among men (34\%) as compared to women $(13.5 \%)$. The age-standardized ratio for cancer incidence is $33.81 \%$, and for mortality is $29.2 \%$ in men alone. ${ }^{24}$ But in our country smoking habit in female is increasing day by day especially in affluent society. Female who smoke got chance more to become a lung cancer. This emphasizes that females may respond differently to tobacco-specific carcinogens for certain cell-types. ${ }^{25,26}$ Several molecular studies have also suggested that sex-differences in lung cancer biology do exist. Examples include, females having higher DNA adduct levels, ${ }^{27}$ an increased CYP1A1 expression, ${ }^{27}$ a decreased DNA repair capacity ${ }^{28}$ and an increased incidence of K-ras gene mutations. ${ }^{29}$ A novel estrogen receptor $\beta$ was also detected in lung tumours, ${ }^{30}$ although both exogenous and endogenous estrogens might be involved in lung cancer development. ${ }^{31}$ All these indicate that estrogen signaling could have a biological role in lung carcinogenesis. Another factor of lung cancer in female is genetic factor called GRPR (Gastrin releasing peptide receptor) is linked to abnormal growth lung cells is more found in women in both smoker and non-smoker than it is in men.

In our study smoking is most common risk factor and among these, active smoker (64.15\%), ex-smoker (18.86\%), nonsmoker including male and female $(16.98 \%)$. In female, smoking is also common risk factor. Also there is definite relationship between smoking in pack year and lung cancer. In our study people with lung cancer consume cigarettes $>40$ pack year risk is $54.17 \%$, 30- 40 pack year risk is $17.92 \%$ and $<30$ pack year least risk $(10.37 \%)$. In other study tobacco smoking is also major cause of all major histological types of lung cancer. In the USA, tobacco use is responsible for nearly 1 in 5 deaths. In 2012, the estimated percentage of new lung cancers in males $(116,470$ cases) and females (109,690 cases) was $14 \%$ each. Among these lung cancers, $29 \%$ of male and $26 \%$ of female cases were estimated to be fatal. Smoking accounts for at least $30 \%$ of all cancer deaths and $87 \%$ of lung cancer deaths. ${ }^{32}$

A carcinogenic effect of tobacco smoke on the lung was demonstrated in epidemiological studies conducted since the early 1950s and has been recognized by public health and regulatory authorities since the mid-1960s. ${ }^{33}$ The geographic and temporal patterns of the disease largely reflect tobacco consumption accumulated during previous decades. ${ }^{34,35}$ The excess risk among continuous smokers relative to that among never-smokers is in the order of 20 to 50 fold. Duration of smoking should be considered the strongest determinant of lung cancer risk in smokers. ${ }^{36}$ The relative risk decreases in ex-smokers, and a 
favorable effect of stopping is apparent even for cessation later in life. However, an excess risk throughout life probably persists even in long-term quitters. ${ }^{35}$

In our study lung cancer occurs more in right site $58.49 \%$ than to left site $41.50 \%$. Probably this is due to nature of right bronchus, which is shorter, wider and more nearer to major bronchus. For this smoking tar and other form of carcinogen enters easily more in right site.

In our study small cell lung cancer $20.75 \%$ and non-small cell lung cancer $79.25 \%$. Adenocarcinoma $35.85 \%$, Squamous cell carcinoma $16.98 \%$, Large cell carcinoma $14.15 \%$, Anaplastic cell carcinoma $8.50 \%$ and others $3.77 \%$. Among other cases, lymphoma $(\mathrm{n}=02)$, neuroendocrine tumor $(n=01)$, sarcomatiod tumor $(n=01)$. This results are almost similar with other established data, where small cell lung cancer $15 \%$, and non-small cell lung cancer $85 \%$, Adenocarcinoma 35-40\%, Squamous cell carcinoma $25-30 \%$, Large cell carcinoma $10-15 \%$. ${ }^{37}$

In our study adenocarcinoma is also more than others type of lung cancer. Adenocarcinoma occurs both in current and ex-smoker but also more seen in nonsmoker, for this reason we found all female patient including smoker and nonsmoker are adenocarcinoma variety. The Irish National Cancer Registry Board based in Cork has been registering lung cancer incident cases from January $1 \mathrm{st}$, $1994 .^{38}$ In total, 10,514 lung cancer incident cases $(6,823$ in males, 3,691 in females) were registered in the Republic of Ireland from 1994 to 2000. Of these, Squamous cell carcinoma was the most frequent cell-type in both males (34\%) and females (22\%), while adenocarcinoma was relatively high among female populations across all the periods studied (18\% vs. $14 \%$ in males). The frequency of Small cell lung cancer was also high in females (17\% vs. $12 \%$ in males); large cell carcinoma was . the least frequent celltype across both sexes (3\%).

Occupational exposures play a significant role in lung cancer etiology, and the risk of lung cancer is increased among workers employed in a number of industries and occupations. ${ }^{39}$ Two studies have reported an estimate of the proportion of lung cancer cases attributable to occupational agents in the UK to be $14.5 \%$ overall $^{40}$ and $12.5 \%$ in men in France. ${ }^{41}$ The most important occupational lung carcinogens are reported to be asbestos, silica, radon, heavy metals and polycyclic aromatic hydrocarbons. But in our study we are unable to detect any relation of specific occupational agents associated with lung cancer.

\section{Conclusion}

For lung cancer prevention, control of tobacco smoking is the most important preventive measure. While the effects of tobacco control in the past few decades on the incidence and mortality of the disease can be appreciated, much remains to be done, in particular among women and in the area of lung cancer screening in smokers using low-dose computed tomography scans. Other priorities for the prevention of lung cancer include control of occupational exposures, as well as indoor and outdoor air pollution, and understanding the carcinogenic and preventive effects of dietary and other lifestyle factors.

\section{References:}

1. Ferlay J, Soerjomataram I, Ervik M,Dikshit $R$,Eser $S$, Mathers $C$, et al.GLOBOCAN 2012 v1.0, Cancer Incidence and Mortality Worldwide: IARC Cancer Base No. 11. Lyon, IARC, 2013.

2. Siegel RL, Miller KD, Jemal A. Cancer statistics, 2015. CA Cancer J Clin. 2015; 65: 5-29.

3. Malvezzi M, Carioli G, Bertuccio P, Boffetta $P$, Levi $F$, VecchiaC La, et al. European cancer mortality predictions for the year 2016 with focus on leukemias. Ann Oncol 2016; 27: 725-31.

4. Foreman $D$, Bray $F$, Brewster $D H$, Gombe Mbalawa $C$, Kohler $B$, Pineros $M$, et al., eds. Cancer Incidence in Five Continents. Volume X. Lyon, International Agency for Research on Cancer, 2014. 
5. Charloux A, Quoix E, Wolkove N, Small $D$, Pauli G, Kreisman $H$. The increasing incidence of lung adenocarcinoma: reality or artefact? A review of the epidemiology of lung adenocarcinoma. Int $J$ Epidemiol. 1997;26(1):14-23.

6. Sun S, Schiller JH, Gazdar AF. Lung cancer in never smokers-A different disease. Nat Rev Cancer. 2007;7:778-90.

7. Hoffmann $D$, Hoffmann I. The changing cigarette, 1950-1995. J Toxicol Environ Health. 1997;50:307-64.

8. National Cancer Institute. SEER Cancer Statistics Review, 1975-2007.

9. Lam TK, Gallicchio L, Lindsley K, Shiels M, Hammond E, Tao G $X$, et al. Cruciferous vegetable consumption and lung cancer risk: a systematic review. Cancer Epidemiol Biomark Prev. 2009; 18: 184-95.

10. World Cancer Research Fund/American Institute for Cancer Research. Food, Nutrition, Physical Activity and the Prevention of Cancer: A Global Perspective. Washington, AICR, 2007.

11. Herr $C$, Greulich $T$, Koczulla RA, Meyer $S$, Zakharkina, Branscheidt, et al. The role of vitamin $D$ in pulmonary disease: COPD, asthma, infection, and cancer. Respir Res. 2011; 12:31.

12. Guertin KA, Freedman ND, Loftfield E, Graubard BI, Caporaso NE, Coffe R, et al. Coffee consumption and incidence of lung cancer in the NIH-AARP Diet and Health Study. Int J Epidemiol. 2015.

13. Clark J, You M. Chemoprevention of lung cancer by tea. Mol Nutr Food Res. 2006; 50:144-151.

14. Mayne ST, Buenconsejo J, Janerich DT. Previous lung disease and risk of lung cancer among men and women nonsmokers. Am J Epidemiol. 1999; 149: 13-20.

15. Wu AH, Fontham ET, Reynolds $P$, Greenberg RS, Buffler $P$, Liff J, et al. Previous lung disease and risk of lung cancer among lifetime nonsmoking women in the United States. Am J Epidemiol. 1995; 141: 1023-32.

16. Gao YT, Blot WJ, Zheng $W$, Zheng $W$, Fraumeni JF, Hsu CW, et al. Lung cancer among Chinese women. Int J Cancer. 1987; 40: $604-9$
17. Aoki K. Excess incidence of lung cancer among pulmonary tuberculosis patients. Jpn J Clin Oncol. 1993; 23: 205-20.

18. IARC Monographs on the Evaluation of Carcinogenic Risks to Humans. Lung. In: lonizing Radiation, Part 1: X- and Gamma (y)-Radiation, and Neutrons. Vol 75. Lyon, World Health Organization/IARC, 2000; pp. 253-54.

19. Boice JD. Ionizing radiation. In: Schottenfeld D, Fraumenu JJ, eds. Cancer Epidemiology and Prevention. New York, Oxford University Press, 1996; pp. 319-54.

20. Cogliano VJ, Baan R, Straif $K$, Grosse $Y$, Lauby-Secretan B, FatihaEl, et al. Preventable exposures associated with human cancers. J Natl Cancer Inst 2011; 103: 1827-39.

21. Rushton L, Hutchings SJ, Fortunato L, Sanjeev B, Beevan $R$, Brown $T$, et al. Occupational cancer burden in Great Britain. Br J Cancer 2012; 107: Suppl 1, S3-S7.

22. Boffetta P, Autier P, Boniol M, Boyle P, Hill $C$, Aurengo A, et al. An estimate of cancers attributable to occupational exposures in France. J Occup Environ Med 2010; 52: 399-406.

23. IARC Monographs. Chemical agents and related occupations. Volume 100 F. A review of human carcinogens. Lyon, World Health Organization/IARC, 2012.

24. Jemal A, Bray F, Center MM, Ferlay J, Ward E, Forman D, et al. Global cancer statistics. CA Cancer J Clin. 2011; 61:69-90.

25. Risch HA, Howe GR, Jain M, Burch JD, Holowaty EJ, Miller $A B$, et al. Are female smokers at higher risk for lung cancer than male smokers? A case-control study by histologic type. Am J Epidemiol. 1993; 138(5):281-93.

26. Haugen A. Women who smokes: are women more susceptible to tobaccoinduced lung cancer? Carcinogenesis. 2002; 23(2):227-9.

27. Mollerup S, Ryberg D, Hewer A, Phillips $D H$, Haugen $A$. Sex differences in lung CYP1A1 expression and DNA adduct levels among lung cancer patients. Cancer Res. 1999; 59(14):3317-20. 
28. Wei Q, Cheng L, Amos Cl, Wang LE, Guo $Z$, Hong WK, et al. Repair of tobacco carcinogen-induced DNA adducts and lung cancer risk: a molecular epidemiologic study. J Natl Cancer Inst. 2000;92(21):1764-72.

29. Nelson HH, Christiani DC, Mark EJ, Wiencke JK, Wain JC, Kelsey KT. Implications and prognostic value of $K$-ras mutation for early-stage lung cancer in women. J Natl Cancer Inst. 1999;91(23):2032-8.

30. Omoto $Y$, Kobayashi $Y$, Nishida K, Tisuchiiya E, Eguchi $H$, Nakagawa K, et al. Expression, function and clinical implications of the estrogen receptor beta in human lung cancers. Biochem Biophys Res Commun. 2001;285(2):340-7.

31. Taioli E, Wynder EL. Re: Endocrine factors and adenocarcinoma of the lung in women. J Natl Cancer Inst. 1994;86(11):869-70.

32. Centers for Disease Control and Prevention Smoking-attributable mortality, years of potential life lost, and productivity losses United States, 2000-2004. MMWR Morb Mortal Wkly Rep. 2008; 57:1226-28.

33. Wynder EL. Tobacco as a cause of lung cancer: some reflections. Am J Epidemiol 1997; 146: 687-94.

34. Peto R, Boreham J, Lopez AD, Thun M, Health $C$ JR. Mortality from tobacco in developed countries: indirect estimation from national vital statistics. Lancet 1992; 339: 1268-78.

35. IARC Monographs on the Evaluation of Carcinogenic Risks to Humans. Tobacco Smoke. In: Tobacco smoke and involuntary smoking. Vol 83. Lyon, World Health Organization/IARC, 2004.

36. Doll R, Peto R, Boreham J, Wheatley K, Gray $R$, Sutherland I,et al. Mortality in relation to smoking: 50 years' observations on male British doctors. BMJ 2004; 328 . 1519.

37. PT Reid, JA Innes; Tumors of the Bronchus and lung. Davidsons Principles and Practice of Medicine. 23rd ed, 2018: 598-603.

38. Walsh PM, Comber H. Patterns of care and survival of cancer patients in Ireland 1994 to 2001: time trends and regional variation for breast, colorectal, lung and prostate cancer. Cork, Ireland: National Cancer Registry Board; 2006.
39. US Department of Health and Human Services. The Health Consequences of Smoking: 50 Years of Progress. A Report of the Surgeon General. Atlanta, U.S. Department of Health and Human Services, Centers for Disease Control and Prevention, National Center for Chronic Disease Prevention and Health Promotion, Office on Smoking and Health, 2014.

40. Devesa SS, Grauman DJ, Blot WJ, Fraumeni JF. Cancer surveillance series: changing geographic patterns of lung cancer mortality in the United States, 1950 through 1994. J Natl Cancer Inst 1999; 91 : 1040-50.

41. Yuan J-M, Koh $W-P$, Murphy SE, Fan $Y$, Wang $R$, Steven $G$, et al. Urinary levels of tobacco-specific nitrosamine metabolites in relation to lung cancer development in two prospective cohorts of cigarette smokers. Cancer Res 2009; 69: 2990-95. 